\title{
CARACTERIZAÇÃO GEOAMBIENTAL DO PARQUE ESTADUAL SERRA DA BOA ESPERANÇA - BOA ESPERANÇA, MG
}

\author{
Manoel Ribeiro Rodrigues Neto ${ }^{1}$ \\ Marta Felícia Marujo Ferreira ${ }^{2}$ \\ Cassiano Gustavo Messias ${ }^{3}$
}

\begin{abstract}
Resumo: O objetivo deste artigo é analisar, de forma integrada, o Parque Estadual Serra da Boa Esperança (PESBE), através do mapeamento temático de variáveis geoambientais que explicam os meios físico e antrópico do parque e da compreensão das inter-relações existentes entre elas, expressas nas unidades de relevo mapeadas. A metodologia consiste na elaboração do mapa de unidades de relevo e no mapeamento e análise de forma integrada das variáveis hipsometria, declividade, uso e cobertura da terra, densidade de drenagem, densidade de lineamentos estruturais e densidade de vias de circulação. Foi constatado que o PESBE abriga uma vasta rede de drenagem, apresenta relevo serrano influenciado pelos litotipos presentes na área e secundariamente pelas estruturas. É majoritariamente recoberto por uma vegetação campestre e marcado por trilhas oriundas da atividade de motociclismo OffRoad. Sugere-se que sejam tomadas medidas para o controle desta atividade, pois ela não condiz com os objetivos de preservação do PESBE.
\end{abstract}

Palavras-chave: Caracterização geoambiental, Análise integrada, Mapeamento temático, Unidade de conservação, Trilhas.

\section{GEOENVIRONMENTAL CHARACTERIZATION OF THE SERRA DA BOA ESPERANÇA STATE PARK - BOA ESPERANÇA, MINAS GERAIS STATE, BRAZIL}

Absctract: This paper aims to analyse, using an integrated approach, the Serra da Boa Esperança State Park (SBESP), through the thematic mapping of geoenvironmental variables that explain the physical and anthropic environments of the park, and their interrelationships, which are expressed in different Relief Units mapped. The methodology consists in the elaboration of the map of relief units and mapping and analysis of variables like hypsometry, terrain slope, land use and land cover, drainage density, structural lineaments density and roads density. It was found that the SBESP, contains wide drainage network, presents mountainous relief influenced by the lithotypes present in the area and secondarily by the structures. It is covered mostly by field vegetation (savanna vegetation) and is affected by several trails formed by Off-Road motorcycling activities. It is suggested that control measures

\footnotetext{
${ }^{1}$ Graduado em Geografia bacharelado pela Universidade Federal de Alfenas (2019) E mestrando do Programa de PósGraduação em Geografia (PPGEO) da Universidade Federal de Alfenas (UNIFAL)

${ }^{2}$ Professora Associada Aposentada da Universidade Federal de Alfenas - UNIFAL

${ }^{3}$ Graduado em Geografia pela Universidade Federal de Alfenas (2012) e Doutor em Geografia, pela Universidade Estadual de Campinas (2018)
} 
must be accomplished, because these activities are not compatible with the SBESP's preservation purpose.

Keywords: Geoenvironmental characterization, Integrated analysis, Thematic mapping, Conservation Units, Trails.

\section{INTRODUÇÃO}

O Cerrado brasileiro é um hotspot de biodiversidade do mundo (MORANDI et al., 2020). É considerado como a região de savana mais rica em espécies no planeta, cobrindo cerca de 2 milhões de $\mathrm{km}^{2}$ do território brasileiro (FRANKE et al., 2018). Com sazonalidade marcante, o Cerrado se encontra no domínio morfoclimático úmido, tendo duas estações bem definidas, uma seca e outra chuvosa, o que reflete em sua estrutura (AB'SÁBER, 2012; CONTI; FURLAN, 2011). A vegetação heterogênea e de sazonalidade acentuada, é composta por formações florestais, savânicas e campestres (ZIMBRES et al., 2020). Em função de suas características, a vegetação herbácea torna-se senescente no período seco, disponibilizando material combustível inflamável sobre o solo, ampliando o potencial de propagação do fogo (DURIGAN; RATTER, 2016; MESSIAS; FERREIRA 2019).

Até a década de 1970 a vegetação do Cerrado havia sido pouco modificada pela ação antrópica (ROSS, 2011), porém, vem sendo severamente degradada ao longo das últimas décadas (ALVES, 2020; SANTOS et al., 2021). Para garantir a proteção de seus ecossistemas de ameaças como o desmatamento florestal e a expansão agrícola, o Brasil investiu na criação e na expansão de áreas protegidas, como as Unidades de Conservação (UC) e Terras Indígenas (TI) (OLIVEIRA et al., 2017). As unidades de conservação são divididas em dois grupos no Sistema Nacional de Unidades de Conservação (SNUC): as Unidades de Proteção Integral, que tem como objetivo principal a preservação da natureza e, por isto, suas categorias apresentam normas mais restritivas; e as Unidades de Uso Sustentável, que permitem conciliar a dinâmica entre proteção do meio ambiente e o desenvolvimento de atividades antrópicas de forma sustentável (BRASIL, 2000).

O Parque Estadual Serra da Boa Esperança (PESBE) é um exemplo de uma Unidade de Proteção Integral do Cerrado. Este Parque foi criado por meio do Decreto Estadual 44.520, de 16 de maio de 2007 (MINAS GERAIS, 2007). Segundo este decreto, o PESBE possui uma área de $5.873,9960$ ha e perímetro de $87.010,51 \mathrm{~m}$, estando sob responsabilidade administrativa do Instituto Estadual de Florestas (IEF) (MINAS GERAIS, op. cit.).

O PESBE é concebido a partir de um importante fato histórico ocorrido no estado de Minas Gerais no final da década de 1950 e início de 1960: a criação da hidrelétrica de Furnas e do seu reservatório. Este empreendimento alterou de maneira drástica a dinâmica socioeconômica e ambiental dos municípios que foram diretamente afetados (MARTINS, 2010; MORAIS et al., 2014). A criação do reservatório provocou a inundação de áreas com relevos detentores de cotas altimétricas mais baixas, fazendo com que a disponibilidade de terras diminuísse, 0 que levou os agricultores e pecuaristas a expandirem suas atividades em direção à Serra da Boa Esperança (IEF, 2020). Desde aquele período houve uma forte substituição de áreas de vegetação nativa por cafeicultura, importante atividade econômica no município de Boa Esperança e na região (MORAIS et al., 2014).

O processo de criação do PESBE foi iniciado pela prefeitura de Boa Esperança e por lideranças locais, com intuito de frear a expansão de áreas agrícolas que 
ocorrem no entorno da Serra da Boa Esperança em direção ao seu interior. A criação do parque prevê também a proteção dos corpos d'água presentes na Serra, fator que aumenta seu valor ecológico e potencial turístico, além de contribuir para o abastecimento de água das comunidades localizadas nas proximidades do parque. Além disto, a criação pretendia reduzir a propagação de fogo em locais no interior do parque que eram afetados pela alta recorrência de queimadas, muitas vezes ocasionadas por atividades turísticas mal planejadas (IEF, 2020; MORAIS et al., 2014).

Devido à categoria de UC que está inserido, no Parque são permitidas atividades recreativas, educativas e de interpretação ambiental, além de pesquisas científicas (BRASIL, 2000). O turismo é uma atividade econômica importante para o município de Boa Esperança e foi levado em consideração ao se criar o PESBE (SANTOS, 2010), porém, deve estar em conformidade com a preservação da natureza. Para que isso ocorra é necessário a elaboração prévia de um bom plano de manejo, aliado ao estudo do uso público nas áreas de visitação. Isto por vezes não ocorre, e a UC recebe visitantes antes mesmo da estruturação de seus respectivos planos de manejo (SILVA; CASTRO, 2015), como tem ocorrido no PESBE, posto que o referido documento ainda se encontra em fase de elaboração. O plano de manejo é o documento mais importante de uma UC, pois estabelece diretrizes para o zoneamento, o diagnóstico e o manejo dos recursos naturais, além de normalizar as pesquisas, a utilização e visitação (SANTOS, 2010).

Com a finalidade de promover uma visão integrada do sistema ambiental do PESBE, o presente artigo objetiva caracterizar esta UC por meio do mapeamento temático de variáveis geoambientais, considerando as inter-relações existentes entre elas (relacionadas especialmente ao meio físico, mas também considerando o meio antrópico), utilizando as unidades de relevo emissoras, transmissoras e coletoras presentes no parque como base para a análise destas inter-relações. As variáveis geoambientais mapeadas e discutidas de maneira conjugada são: hipsometria, declividade, uso e cobertura da terra, densidade de drenagem, densidade de lineamentos estruturais e densidade de vias de circulação, as quais permitem auxiliar no entendimento das dinâmicas socioambientais no contexto local da UC.

É importante destacar a carência de estudos de cunho geográfico no PESBE, fato que dificulta o conhecimento da área no meio científico e que foi um dos motivos para o início tardio da elaboração do plano de manejo. A caracterização das variáveis geoambientais realizada neste trabalho é fundamental para a compreensão do quadro natural e antrópico do parque. Estas variáveis, servirão de subsídio para a realização de novas pesquisas no arcabouço da Geografia para esta importante e, relativamente, recente Área de Proteção Integral.

\section{ÁREA DE ESTUDO}

Á área deste estudo (Figura 1) corresponde aos terrenos que integram o Parque Estadual Serra da Boa Esperança, Unidade de Conservação que está localizada no município de Boa Esperança, Minas Gerais, entre as coordenadas

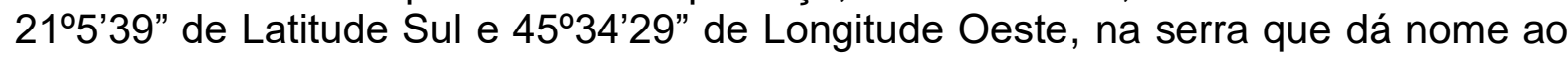
parque (IEF, 2020). 
Figura 1. Área de localização do Parque Estadual Serra da Boa Esperança

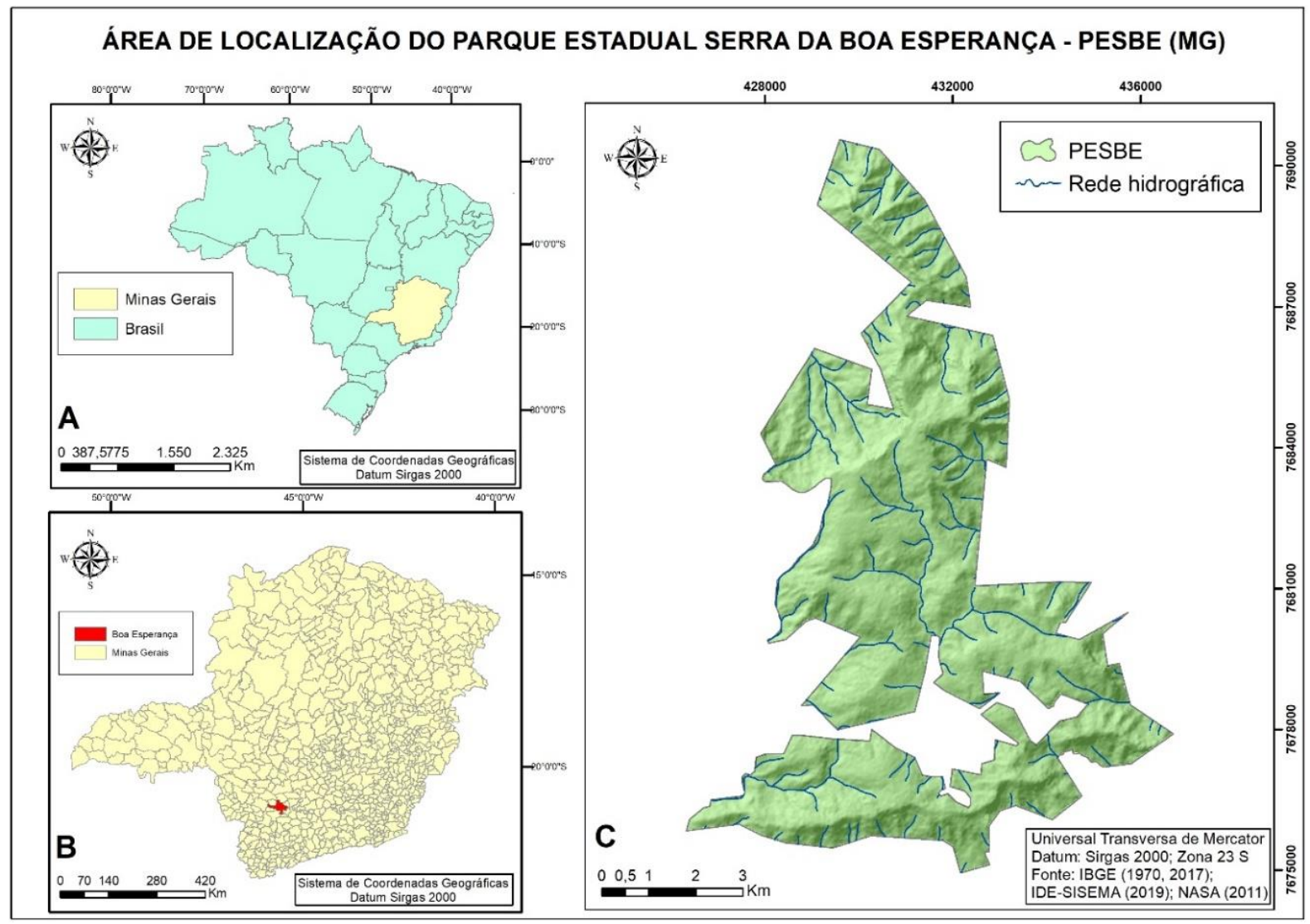

Fonte: Elaborado pelos autores (2021)

Legenda: A - Localização do estado de Minas Gerais no Brasil

B - Localização do município de Boa Esperança em Minas Gerais

C - Delimitação do PESBE

O PESBE está totalmente inserido no Cerrado segundo a classificação do IBGE (2017), porém, em uma região de transição entre os domínios do Cerrado e da Mata Atlântica. De acordo com Rangel (2017), no parque predomina a fitofisionomia Campo de Altitude, com significativa ocorrência de fragmentos de Floresta Estacional Semidecidual.

O PESBE apresenta grande importância ecológica (IEF, 2020). Alves (2019) em seu estudo sobre os mamíferos de médio e grande porte do parque identificou diversas espécies, como o Lobo-guará, a Onça parda, a Jaguatirica, o Tamanduábandeira, o Cachorro-do-mato, a Paca e a Irara. A UC também abriga uma grande diversidade de aves, com espécies comuns e raras, tais como o Tico-tico, o Gavião carcará, o Bico de veludo e a Noivinha branca (COUTINHO; ANDRADE, 2016).

No que se refere aos aspectos climáticos, tem-se que o clima da região onde o PESBE está inserido é do tipo tropical de altitude (Cwa), apresentando temperaturas amenas, possuindo médias anuais que variam entre 21 e $23 \cong \mathrm{C}$ e chuvas torrenciais concentradas no verão, enquanto o inverno é caracterizado como o período seco (PDRH FURNAS, 2013).

Com base nas pesquisas desenvolvidas por Valeriano (1992) e nos mapeamentos geológicos elaborados por Valeriano et al. (2007) e Ribeiro et al. (2020) para a região do PESBE, constata-se que o arcabouço litológico da área é formado por rochas pré-cambrianas metamorfisadas, datando do Arqueano e Proterozóico, 
sendo provenientes tanto de rochas sedimentares como magmáticas. Este arcabouço é distribuído espacialmente em unidades lito-estratigráficas a saber:

- Granitos e Ortognaisses - aparecem milonitizados e/ou filonitizados. Estes têm ocorrência restrita ao sul do PESBE, na face norte da Serra da Boa Esperança, abrangendo um trecho a montante da bacia do ribeirão Águas Verdes;

- Xisto Costas - formados por epidoto-muscovita xisto feldspático vulcanoclástico, ocorrem de maneira localizada, nos limites do parque, ao longo dos setores sudeste, leste e nordeste do PESBE;

- Sequência Serra da Boa Esperança 1 - apresenta unidade metapelítica; filitos sericíticos cinzentos ou esverdeados; metarritmito arenoso. Têm distribuição restrita na área, especialmente em alguns trechos na média vertente e no sopé da Serra da Boa Esperança, ocorrendo a leste, nordeste, norte e noroeste da serra, circunscrita a faixas altimétricas entre 783 a $1.143 \mathrm{~m}$;

- Sequência Serra da Boa Esperança 2 - unidade quartzítica constituída por metarenitos ortoquartzíticos; filitos sericíticos subordinados; lentes de metaconglomerados quartzíticos. Esta unidade tem ampla distribuição no PESBE, ocorrendo ao sul do parque, na face sul da Serra da Boa Esperança e nas faixas altimétricas mais elevadas entre 1.143 a $1.395 \mathrm{~m}$ se distribuindo nas áreas de topos planos/ tabulares em grande parte do setor central e nas cristas agudas/retilíneas ao norte da Serra da Boa Esperança;

- Formação Samburá - metapelito maciço ou laminado. Tem pouca ocorrência se restringindo em poucos trechos a noroeste e ao sul do parque.

Gatto et al. (1983) ressaltam que a área integra o Domínio Morfoestrutural dos Remanescentes de Cadeias Dobradas, composto pelos subdomínios Região dos Planaltos da Canastra e Região dos Planaltos do Rio Grande, estando a área do PESBE inserida neste último subdomínio.

O mapa de Compartimentos Morfoestruturais proposto por Valeriano et al. (2007) das folhas Guapé e Alpinópolis mostra a presença de forte influência das características litológicas nos compartimentos de relevo. São eles: A - Compartimento de Serras e Cristas Quartzíticas, subdividido em segmentos A1, A2 e A3; B Compartimento de Serras e Cristas Gnáissicas; C - Compartimento de Colinas e Morros Embutidos.

O segmento A1, corresponde aos Planaltos da Canastra tendo um conjunto morfológico marcado pelo Chapadão da Zagaia ou da Babilônia com cotas máximas de $1350 \mathrm{~m}$. Os chapadões definem um relevo de topos aplainados com linhas de cristas residuais e vales encaixados delimitados por escarpas íngremes. A drenagem presente, disseca as escarpas gerando gargantas e cânions. O segmento $A 2$, é caracterizado pela presença das serras da Pimenta e Itaipava e de linhas de cristas do tipo hogbacks, possuem altitudes entre 1.000 e $1.100 \mathrm{~m}$. Embutida entre as serras ocorre uma depressão, atualmente alagada pela construção de um dique no rio Piumhi, próximo a Capitólio. O segmento A3, corresponde a um trecho da folha Guapé onde se insere a área de estudo. Este segmento é caracterizado pela presença de linhas de cristas do tipo hogbacks com direções N-NW e N-S. Os vales fluviais se encaixam paralelamente às cristas, como é o caso das bacias do ribeirão Verde e do ribeirão Águas Verdes.

No que concerne a hidrografia, o PESBE apresenta recursos hídricos abundantes. As cachoeiras e corredeiras encontradas no parque contribuem para sua grande beleza cênica e potencial turístico e seus diversos cursos d'água tributários do Rio Grande e do Lago de Furnas abastecem propriedades e comunidades localizadas no sopé da Serra da Boa Esperança (IEF, 2020). 


\title{
METODOLOGIA
}

\author{
MATERIAL
}

O levantamento e a revisão dos materiais bibliográficos e cartográficos foram fundamentais para alcançar os objetivos propostos na pesquisa. Foram utilizados materiais cartográficos e produtos de sensoriamento remoto, tais como: cartas topográficas de Boa Esperança e Cristais, em escala 1: 50.000, geradas pelo IBGE; imagem de alta resolução espacial (0,5 m) MAXAR, com data de 30 de maio de 2019 e Modelo Digital de Elevação (MDE) Advanced Land Observing Satellite (ALOS) Phased Array type L-band Synthetic Aperture Radar (PALSAR) Radiometric Terrain Correction (RTC), com resolução espacial de 12,5 m.

Os softwares utilizados para a realização dos procedimentos referentes ao mapeamento e a análise proposta foram o Google Earth Pro e o ArcGIS 10.5. Ambos os softwares se encontram disponíveis nos laboratórios de Geoprocessamento do curso de Geografia, da Universidade Federal de Alfenas - UNIFAL- MG.

\section{PROCEDIMENTOS METODOLÓGICOS}

A metodologia adotada neste artigo baseou-se na integração de variáveis do meio físico e antrópicas com base na abordagem sistêmica, que permitiu o entendimento da área do PESBE de forma integrada, considerando as conexões existentes entre os atributos que compõem o meio físico e antrópico. Segundo Gregory (1992) a abordagem sistêmica envolve um conjunto teórico-metodológico fundamentado na análise integrada dos elementos constituintes de um sistema, visando compreender suas relações entre si e com o meio ao redor.

Para a análise integrada do PESBE, adotou-se como critério básico de definição as unidades de relevo do parque. Sendo assim, cada unidade de relevo foi analisada a partir das inter-relações entre as características físicas e antrópicas, representadas através de mapas temáticos. Essa análise foi realizada por meio da observação visual, na tela do computador, da espacialização das variáveis geoambientais nas unidades de relevo, o que permitiu visualizar as relações existentes entre estas variáveis e tratá-las de formas integrada.

O mapeamento temático realizado neste trabalho consiste na elaboração dos mapas de Hipsometria, Declividade, Uso e Cobertura da Terra, Densidade de Drenagem, Densidade de Lineamentos Estruturais e Densidade de Vias de Circulação. Estes mapas foram projetados no sistema de coordenadas planas Universal Transversa de Mercator (UTM) e com o datum Sirgas 2000. Com exceção da hipsometria, os mapas foram gerados por meio do método de atribuição de intervalos de classes por quebras naturais, que identifica rupturas naturais na série de dados originais por meio do histograma de frequência de valores dos mapas, e visa a não interferência subjetiva do pesquisador na distribuição dos dados em classes (FERREIRA, 2014). Já o mapa hipsométrico foi produzido por intervalos iguais, visando maior fidelidade às características do relevo, por meio de uma representação em que as classes possuem a mesma amplitude de valores.

Os procedimentos metodológicos para a elaboração do mapa de unidades de relevo e do mapeamento temático das variáveis geoambientais serão descritos a seguir. 
O mapa de Unidades de Relevo foi elaborado a partir da análise e interpretação visual de imagens do Google Earth e de cartas topográficas (escala 1:50.000) das folhas Boa Esperança e Cristais que abrangem o PESBE. Foram definidas 5 unidades de relevo, a saber: 1 - Interflúvio Angular/Agudo; 2 - Interflúvio Plano/Tabular; 3 - Escarpa; 4 - Rampa Intermediária de Transporte; 5 - Sopé Coluvial.

A delimitação destas unidades foi realizada manualmente, sobre cartas topográficas impressas, com base na identificação e no traçado das grandes rupturas de declive, e considerando as categorias funcionais do relevo de Sato e Cunha (2013). Com base nas autoras citadas (2013), foram mapeadas unidades emissoras, transmissoras e coletoras de matéria e energia. As unidades emissoras são as que apresentam um "maior potencial para a deflagração de processos erosivos associados a altas cargas de energia" (SATO; CUNHA, 2013, p. 336). As unidades transmissoras correspondem as rampas geralmente mais íngremes, que possuem "maior suscetibilidade aos processos denudacionais" (SATO; CUNHA, 2013, p. 336). Por fim, as unidades coletoras "tem a função de receber e reunir os fluxos de matéria e energia" (SATO; CUNHA, 2013, p. 337), definindo as áreas de depósitos ou acumulação de materiais.

Neste artigo, considerou-se como referência para a delimitação das unidades de relevo homogêneas, as rupturas convexas positivas, que delimitam unidades emissoras e transmissoras e as rupturas côncavas negativas, que delimitam unidades coletoras de acordo com a metodologia utilizada por Sato e Cunha (2013).

Finalizado o mapeamento das unidades de relevo sobre as cartas topográficas impressas, foi realizada a vetorização das mesmas no SIG ArcGis 10.5. Através do módulo Editor, foram criados arquivos vetoriais no formato shapefile de polígonos referentes a cada Unidade de Relevo, assim como foram criados arquivos vetoriais de linhas correspondendo às rupturas de declive côncavas e convexas. Por fim, foram atribuídas cores aos polígonos das unidades de relevo, e foram realizadas edições nos arquivos vetoriais de linhas referentes as rupturas de declive, para que atendessem aos padrões da cartografia geomorfológica. Foi gerada uma legenda demonstrando a simbologia de todas as feições mapeadas.

\section{HIPSOMETRIA}

O mapa hipsométrico foi produzido com base no MDE resultante do projeto ASF' Radiometric Terrain Correction Project, que teve como finalidade corrigir geometria e radiometria de produtos provenientes de Radar de Abertura Sintética (SAR) para produzir um produto de melhor qualidade. Para o território brasileiro foi usado o modelo SRTM, cuja resolução espacial era de $30 \mathrm{~m}$, gerando um produto MDE reamostrado para 12,5 m (ASF, 2020), o qual foi utilizado nesta pesquisa. O MDE é uma representação digital da superfície constituída por uma matriz de pixels com coordenadas $(\mathrm{x}, \mathrm{y})$, e associado a um valor que corresponde à elevação (z) do terreno. O MDE é um dos principais produtos utilizados na modelagem do terreno em SIG, pois permite criar representações de parâmetros morfológicos, tais como hipsometria, declividade, curvatura e orientação das vertentes (ZHOU; LIU, 2004).

O MDE ALOS PALSAR RTC foi recortado conforme o limite do PESBE, por meio da ferramenta Clip, no ArcGIS 10.5. Para a elaboração do mapa hipsométrico 
os valores de altitude foram agrupados em classes de altitude, sendo, em seguida, atribuída uma paleta de cores.

DECLIVIDADE

O mapa de declividade foi produzido por meio da ferramenta Slope, encontrada em Spatial Analyst Tools no ArcGIS 10.5. Como raster de entrada foi utilizado o MDE ALOS PALSAR RTC, e os valores de declividade foram gerados em graus. Por fim, foram geradas as classes e atribuída uma paleta de cores.

\section{USO E COBERTURA DA TERRA}

O mapa de uso e cobertura da terra foi produzido com base em imagem MAXAR (ARCGIS, 2021), com resolução espacial de 0,5 m e com data de 30/05/2019. A imagem foi importada por meio da ferramenta Add basemap, contida no ArcGIS 10.5 , sendo que este produto possui excelente contraste e georreferenciamento. $O$ mapeamento foi realizado por meio de interpretação visual e em escala 1:5.000, sendo que foram diferenciadas sete classes de uso e cobertura: mata, campo limpo, campo sujo, pastagem, silvicultura, solo exposto e área agrícola (café).

\section{DENSIDADE DE DRENAGEM}

O mapeamento da densidade de drenagem representa um índice morfométrico que correlaciona o comprimento total dos canais (em $\mathrm{km}$ ) em uma determinada unidade de área $\left(\mathrm{km}^{2}\right)$. Para a obtenção da densidade de drenagem foi utilizado o estimador Kernel, que, para o cálculo da densidade realiza a contagem de todas as linhas dentro em uma região de influência, ponderando-as pela distância de cada uma à localização de interesse (CÂMARA; CARVALHO, 2002).

Para a geração do mapa de densidade de drenagem foi empregado como feição de entrada um arquivo vetorial que representa a rede de drenagem do PESBE. Estas feições foram extraídas das cartas topográficas por meio do processo de vetorização em SIG. Não foi vetorizada apenas a drenagem contida no interior do parque, mas também aquela localizada a um raio de $3 \mathrm{~km}$ de seus limites - sendo esta considerada como a área de influência do parque. Este procedimento foi essencial para que se pudesse obter a estimativa das densidades condizente com a realidade terrestre, considerando a influência externa ao PESBE.

O mapa de densidade de drenagem foi gerado através da ferramenta Kernel Density, contida em Spatial Analyst tools do ArcGIS 10.5. Após vários testes, o raio de $1 \mathrm{~km}$ foi eleito como padrão para estimativas de densidade no PESBE. Depois de gerado o arquivo raster de densidade, o mesmo foi recortado apenas para o interior do parque. Cada pixel no mapa apresenta a estimativa de quantos quilômetros de vias estão contidos em cada quilômetro quadrado.

\section{DENSIDADE DE LINEAMENTOS ESTRUTURAIS}

Os lineamentos estruturais no PESBE e em sua área de influência foram identificados visualmente, com base na metodologia apresentada por Soares e Fiori (1978). Sobre a rede de drenagem e utilizando o sombreamento do relevo como camada auxiliar, foram identificados trechos da drenagem retilíneos ou que apresentavam ângulos abruptos, caracterizando os lineamentos estruturais. Foi criado 
um arquivo vetorial contendo o mapeamento dos lineamentos, que foi gerado por meio de funções da barra de ferramentas Editor.

Este arquivo vetorial foi utilizado como feição de entrada para realizar a estimativa da densidade de lineamentos estruturais. Para aplicação do estimador Kernel, foi utilizada a ferramenta Kernel Density, no ArcGIS 10.5, e o produto foi apresentado em quilômetros de lineamentos por quilômetros quadrados.

\section{DENSIDADE DE VIAS DE CIRCULAÇÃO}

As vias de circulação identificadas neste trabalho englobam as estradas não pavimentadas (vias principais), por onde circulam os veículos automotores, e as trilhas (vias secundárias), por onde costumam circular motocicletas, devido à prática de motociclismo Off-Road, e visitantes que buscam se aproximar do ambiente natural ou chegar a atrativos específicos, como, por exemplo, cachoeiras do Complexo Santa Luzia. A identificação e vetorização das vias de circulação foi realizada no Google Earth Pro, no qual anteriormente foi criada uma pasta na camada "meus lugares", para que as vias vetorizadas fossem salvas. Após modificar o sistema de coordenadas do software para coordenadas planas UTM, as vias de circulação foram vetorizadas por meio da função "adicionar caminho". Foi adotada uma altitude do ponto de visão de $1,9 \mathrm{~km}$. Após a finalização do mapeamento, a pasta contendo as linhas foi salva em formato KML.

Em seguida foi feita a conversão do arquivo KML em layer, no ArcGIS 10.5 e o produto foi salvo em um novo arquivo vetorial, no formato shapefile. O estimador Kernel foi empregado no cálculo da densidade de vias de circulação, por meio da ferramenta Kernel density, e foi aplicando como arquivo vetorial de entrada as vias anteriormente mapeadas. A densidade foi expressa em quilômetros de vias por quilômetros quadrados.

\section{RESULTADOS E DISCUSSÃO}

As variáveis geoambientais utilizadas revelam que o PESBE apresenta uma diversidade físico-geográfica, o que faz com que esta UC seja um território a ser preservado, visando a manutenção da biodiversidade e da geodiversidade. De maneira geral, o relevo serrano é predominante na UC, sendo formado por topos tabulares e estreitos e morros com vertentes suaves e íngremes, gerando inúmeros escarpamentos. O front das escarpas formadas na Serra da Boa Esperança ao sul do parque e na Serra do Chapadão ao noroeste, exibe vertentes íngremes, desenvolvendo anfiteatros de erosão marcados pelos canais de $1^{\underline{a}}$ e $2^{\underline{a}}$ ordens. As faces íngremes destes escarpamentos se configuram em escarpas de linha de falha, que seguem recuadas em função das pequenas bacias de drenagem.

\section{CARACTERIZAÇÃO DAS VARIÁVEIS GEOAMBIENTAIS DO PESBE}

\section{HIPSOMETRIA}

O PESBE apresenta altitudes que variam de 783 a $1.395 \mathrm{~m}$, sendo que a diferença entre as maiores e as menores altitudes em todo o parque demonstram uma amplitude altimétrica de $612 \mathrm{~m}$, conforme mostra o mapa hipsométrico (Figura 2). A menor altitude, $783 \mathrm{~m}$, é encontrada no nível de base dos principais rios das bacias do Ribeirão Verde e do Ribeirão Águas Verdes. A classe que apresenta as menores 
altitudes varia entre 783 a 936 m e se localiza em áreas próximas ao limite do parque, nos setores sul, nordeste, noroeste e norte.

As altitudes entre 937 e 1.242 m são encontradas em grande área do PESBE, circunscritas aos morros e as médias vertentes dos relevos mais elevados, além dos morros menos elevados que são formados por topos planos/tabulares ou levemente arredondados situados no setor central, sudeste e sudoeste do PESBE e trechos da crista da Serra da Boa Esperança.

Por sua vez as altitudes mais elevadas, as quais variam entre o intervalo 1.243 e $1.395 \mathrm{~m}$, ocorrem predominantemente nos setores sul, sudeste, central e noroeste. Estão relacionadas com as cristas estreitas e arredondadas e aos topos aplainados da Serra da Boa Esperança e da Serra do Chapadão.

É importante destacar que a delimitação do PESBE foi estabelecida nas áreas de topografias mais rebaixadas, no sopé da Serra da Boa Esperança, visando a preservação e a conservação dos ecossistemas montanhosos - os quais estão posicionados em áreas mais centrais. Entre as áreas mais rebaixadas do relevo, destacam-se os vales dos baixos trechos do Ribeirão Águas Verdes e do Ribeirão Verde, sistemas fluviais responsáveis pelos remanescentes e festonamentos da Serra da Boa Esperança e do Chapadão (Figura 2).

\section{DECLIVIDADE}

As declividades no PESBE variam de 0 a 76,40 $\cong$ (Figura 2). As menores declividades ( 0 a $11,98^{\circ}$ ) têm destaque nos topos planos/tabulares ou levemente arredondados dos morros do setor central do PESBE. Esta classe de declividade ocorre também em algumas planícies aluviais estreitas de rios por toda a área de estudo, além de áreas de depósito coluvionar no sopé da Serra da Boa Esperança, sul do parque. As declividades médias (11,99 a 30,86 ํ) se distribuem em grande parte dos terrenos do PESBE, sendo predominantes no setor norte e comumente encontradas nas médias vertentes dos morros no setor central, sul e sudeste.

Por outro lado, as maiores declividades (30,87 a 76,40ํ) estão frequentemente associadas às vertentes escarpadas das serras da Boa Esperança e do Chapadão. A Serra da Boa Esperança possui papel de destaque nesse quesito, pois apresenta faces escarpadas em diversos trechos, como nos setores sul, leste, nordeste e norte do parque. Ademais, os altos valores de declividade são encontrados na parte superior do front da Serra do Chapadão, em sua borda; e em vertentes de morros festonados no setor nordeste.

\section{USO E COBERTURA DA TERRA}

O PESBE apresenta sete classes de uso e ocupação da terra (Figura 2), porém três delas possuem maior destaque na área, sendo elas: campo limpo, mata e campo sujo. O campo limpo, caracterizado como uma fitofisionomia constituída por estrato herbáceo e quase completa ausência de espécies lenhosas (COUTO JUNIOR et al., 2010), ocupa a maior área da UC, abrangendo $24,12 \mathrm{~km}^{2}$, ou $41 \%$ de seu território. Ocorre principalmente no setor central, mas também está presente em áreas consideráveis nos setores sul, sudeste, centro-sul e nordeste, onde se intercala com campos sujos, fitofisionomia formada por vegetação herbácea e por indivíduos arbustivos esparsos (COUTO JUNIOR et al., 2010). Os campos sujos, se constituem na terceira classe de uso e cobertura da terra com maior ocorrência no PESBE, abrangendo $15 \%$ de suas terras ou ainda uma área de $8,67 \mathrm{~km}^{2}$. Ambientes com 
características de cobertura vegetal similares ocorrem nos chapadões quartzíticos do Parque Nacional da Serra da Canastra, UC localizada a menos de $70 \mathrm{~km}$ do PESBE, e estudos indicam elevada propensão à propagação de queimadas nestes locais (MESSIAS; FERREIRA, 2019).

Por sua vez, a mata se caracteriza como a classe de uso e cobertura da terra com a segunda maior ocorrência no PESBE, estendendo-se por uma área de 22,48 $\mathrm{km}^{2}$, o que equivale a $38 \%$ de sua área total. Esta classe abrange principalmente os setores sul, sudeste, noroeste, nordeste e norte, onde existem fragmentos de floresta estacional semidecidual, que ocorrem de maneira significativa no parque (RANGEL, 2017). Se localizam próximos aos limites do parque e, em trechos específicos, como em áreas situadas no sopé da Serra da Boa Esperança, em contato com áreas de cultivo de café. Além disto, a classe mata, no PESBE, diz respeito às matas ciliares e às matas de galeria, fitofisionomias que acompanham os rios e córregos no Cerrado, protegendo as margens da ocorrência de processos erosivos (RIBEIRO; WALTER, 1998; MESSIAS; FERREIRA, 2019), estando presentes de forma significativa na bacia do Ribeirão Águas Verdes.

Em diversas áreas do PESBE, principalmente nos setores leste, nordeste, noroeste e norte, os fragmentos florestais estão associados a pastagens, principalmente nas áreas limítrofes da UC. As pastagens estão presentes em $4 \%$ dos terrenos do PESBE, ocupando uma área total de $2,59 \mathrm{~km}^{2}$, com destaque para o setor leste, onde se intercalam com mata, campo limpo e área de cultivo de café.

As áreas de cultivo de café, assim como a silvicultura, ocupam aproximadamente $1 \%$ dos terrenos do PESBE, ambas abrangendo áreas com aproximadamente $0,4 \mathrm{~km}^{2}$. Entretanto, a classe cultivo agrícola (café) distribui-se espacialmente em diversos pequenos polígonos, espalhados pelos setores sul, centro-sul, sudeste, leste e norte; já a classe silvicultura ocorre em dois polígonos, um no setor centro-sul e outro no setor norte.

A classe solo exposto tem ocorrência muito restrita no PESBE, ocupando menos de $1 \%$ da área total do parque, totalizando apenas $0,03 \mathrm{~km}^{2}$. Sua ocorrência se restringe as áreas limítrofes da UC, sendo dois polígonos muito pequenos no setor nordeste e um, com área um pouco maior, no setor norte. 
Figura 2. Mosaico dos mapas hipsométrico, de declividade, e de uso e ocupação da terra, do Parque Estadual Serra da Boa Esperança - MG

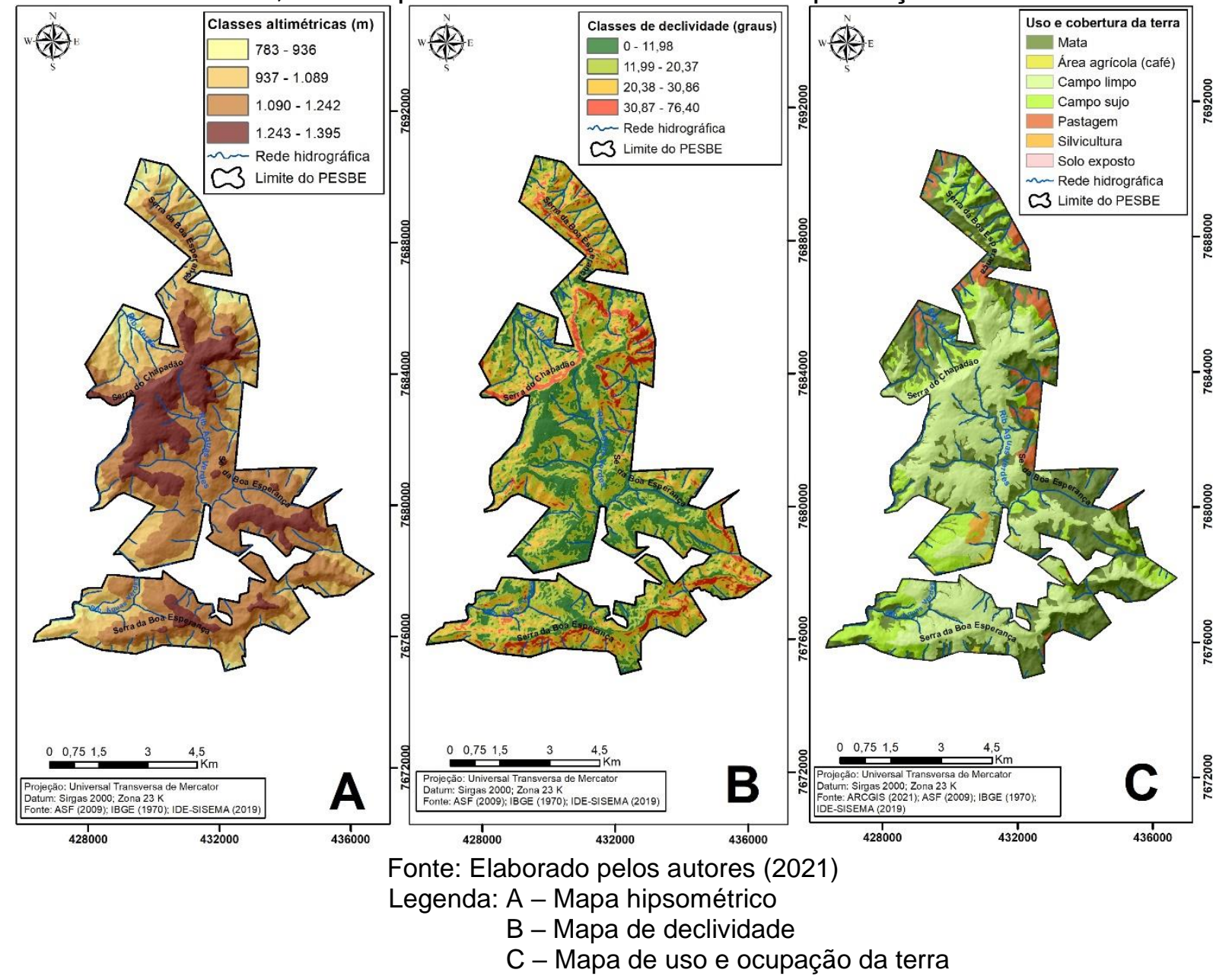

\section{DENSIDADE DE VIAS DE CIRCULAÇÃO}

Através do mapeamento da densidade de vias de circulação (DVC) do PESBE, foi constatado a presença intensa de trilhas oriundas da atividade de motociclismo OffRoad, que se apresentam conectadas nas áreas centrais do parque.

As densidades de vias variam de 0 a $6,240 \mathrm{~km} / \mathrm{km}^{2}$ (Figura 3). A classe de menor densidade $(0$ a 1,052) é encontrada predominantemente nos setores sul, noroeste, norte e em uma área que abrange parte dos setores nordeste e centro-norte. Já a classe que representa os valores intermediários de DVC $\left(1,053\right.$ a $\left.3,670 \mathrm{~km} / \mathrm{km}^{2}\right)$ localiza-se principalmente nos setores sul, sudeste, centro-oeste, nordeste e norte. Por fim, os maiores valores de DVC (3,671 a 6,240 km/ $\left.\mathrm{km}^{2}\right)$ localizam-se predominantemente nos setores central, centro-leste e sudeste, e de maneira secundária nos setores sul, centro-sul, nordeste e norte. Os altos índices de DVC no setor centro-leste, estão associados à grande quantidade de trilhas causadas pelo motociclismo Off-Road, na Serra da Boa Esperança. As trilhas estão dispostas sobre a crista da Serra e em diversos trechos de suas vertentes.

A presença intensa destas trilhas relaciona-se à beleza cênica dos picos da Serra da Boa Esperança, com visão panorâmica da paisagem no entorno. Ao mesmo tempo, o relevo serrano não se configura como uma barreira para a prática do 
motociclismo Off-Road, pelo contrário, pelas características topográficas, é um atrativo aos praticantes da atividade.

Sendo assim, torna-se importante frisar que, Fonseca Filho; Varajão e Castro (2019), estudando parques do Quadrilátero Ferrífero e da Serra do Espinhaço Meridional, constataram que a erosão e compactação nestas áreas protegidas são decorrentes do uso desordenado de trilhas, meios de acesso aos principais atrativos. Segundo os autores, as trilhas "podem causar danos ambientais abióticos, como deslizamentos; e bióticos, como supressão de vegetação e de fauna" (FONSECA FILHO; VARAJÃO; CASTRO, 2019, p. 835).

\section{DENSIDADE DE DRENAGEM}

O mapa de densidade de drenagem (Dd) apresenta valores entre 0,091 a 3,048 $\mathrm{km} / \mathrm{km}^{2}$ (Figura 3). As menores densidades de drenagem do PESBE $(0,091$ a 0,984 $\mathrm{km} / \mathrm{km}^{2}$ ) são encontradas principalmente nos setores sul, sudeste, centro-sul, centrooeste e centro-norte do parque. Já os valores intermediários de densidade $(0,985$ a $2,063 \mathrm{~km} / \mathrm{km}^{2}$ ) são observados em diversas áreas do parque, principalmente nos setores norte, nordeste, sul e central. Por outro lado, maiores densidades de drenagem $\left(2,064\right.$ a $\left.3,048 \mathrm{~km} / \mathrm{km}^{2}\right)$ estão presentes de maneira mais significativa nos setores central, norte, noroeste, leste, centro-sul e sul.

A densidade de drenagem possui uma forte relação com as características de permeabilidade/impermeabilidade do terreno, sendo que os terrenos mais impermeáveis apresentam uma rede de drenagem mais densa ao passo que os mais permeáveis apresentam uma rede de drenagem menos densa (BIGARELLA, 2007).

Sendo assim, o comportamento da densidade de drenagem do PESBE (Figura 6) pode ser explicado por meio da análise das litologias presentes no parque. Como mencionado anteriormente, a caracterização geológica da área mostra o predomínio de quartzitos e metarenitos, seguidos por metapelitos, filitos, xistos e granitos e ortognaisses milonitizados.

De maneira geral, o comportamento hidrológico das rochas que ocorrem na área, dado pela composição mineralógica, favorece a permeabilidade e percolação das águas, resultando em baixas densidades de drenagem em uma grande área do parque. Essa análise é reforçada pela presença de granitos e ortognaisses em toda a face norte da Serra da Boa Esperança, ao sul do parque, que se encontram milonitizados. Esta característica pode resultar no alto grau de fraturamento, o que favorece a infiltração e percolação para os lençóis subterrâneos.

Por outro lado, a ocorrência de altas densidades de drenagem em algumas áreas do parque, como em setores da bacia do Ribeirão Águas Verdes e do Ribeirão Verde e em áreas de nascente vinculadas a crista da Serra da Boa Esperança, no setor norte, indicam que o comportamento hidrológico das rochas nestas áreas dificulta a infiltração e a percolação das águas pluviais.

\section{DENSIDADE DE LINEAMENTOS ESTRUTURAIS}

Os lineamentos estruturais se relacionam com a zonas de fraturamento, que segundo Soares e Fiori (1978, p.48), "por serem mais facilmente atacadas pelos processos meteóricos e erosivos, constituem zonas de desenvolvimento preferencial de linhas de drenagem retilíneas". Ainda segundo os autores (op. cit.), estes elementos de drenagem são condicionados pela estrutura geológica, que se apresentam como retilíneos ou em arco, chamados de lineações de drenagem. 
O mapa de densidade de lineamentos estruturais (DLE) demonstra que o parque apresenta densidades que variam de 0 a 2,163 km/ $\mathrm{km}^{2}$ (Figura 3). As menores densidades $\left(0\right.$ a $0,373 \mathrm{~km} / \mathrm{km}^{2}$ ) localizam-se principalmente em áreas periféricas, próximas aos limites da UC, nos setores sul, sudeste, sudoeste, oeste e norte, onde predominam canais de primeira ordem, sem controle estrutural. Já os valores intermediários de densidade de lineamentos $\left(0,374\right.$ a $\left.1,179 \mathrm{~km} / \mathrm{km}^{2}\right)$ ocupam grande parte do parque, áreas nos setores sul, central, noroeste, nordeste e norte. As maiores densidades $\left(1,180\right.$ a $\left.2,163 \mathrm{~km} / \mathrm{km}^{2}\right)$ são encontradas nos setores sul, central, noroeste, norte e nas imediações do setor nordeste, estando atreladas às bacias dos ribeirões Verde e Águas Verdes; às bacias de $1^{\underline{a}}$ e $2^{\underline{a}}$ ordem do setor norte e a bacia de $2^{-}$ordem nas proximidades do setor nordeste.

Os valores mais elevados de densidade de lineamentos estruturais identificados nos setores central e noroeste do parque ocorrem nas proximidades do encontro da Serra do Chapadão com a Serra da Boa Esperança, área onde há trechos superiores dos rios de maior ordem hierárquica, o Ribeirão Verde e o Ribeirão Águas Verdes - ambos de $3^{\mathrm{a}}$ ordem. Com base em Soares e Fiori (1978), constata-se que nos rios desta área, predominam trechos retilíneos sobre os curvos, indicando a presença de zonas de fraqueza estrutural ou o condicionamento de parte destes canais por unidades litoestruturais, o que reflete na alta concentração de lineamentos, com orientações predominantes NW-SE e E-W.

Entretanto, é importante ressaltar que uma parte considerável dos lineamentos estruturais está relacionada a canais de primeira ordem, que apresentam a sinuosidade de seus leitos influenciada pela morfologia das vertentes e não por zonas de fraturamento. Sendo assim, afirma-se que mesmo que as sub-bacias que apresentaram os maiores valores de DLE possuam um certo controle estrutural, não é possível afirmar com base nas lineações da drenagem que existam grandes zonas de fraqueza estrutural no parque, sendo necessários estudos mais aprofundados. 
Figura 3. Mosaico dos mapas de densidade de vias de circulação, densidade de drenagem e densidade de lineamentos estruturais, do Parque Estadual Serra da

Boa Esperança - MG
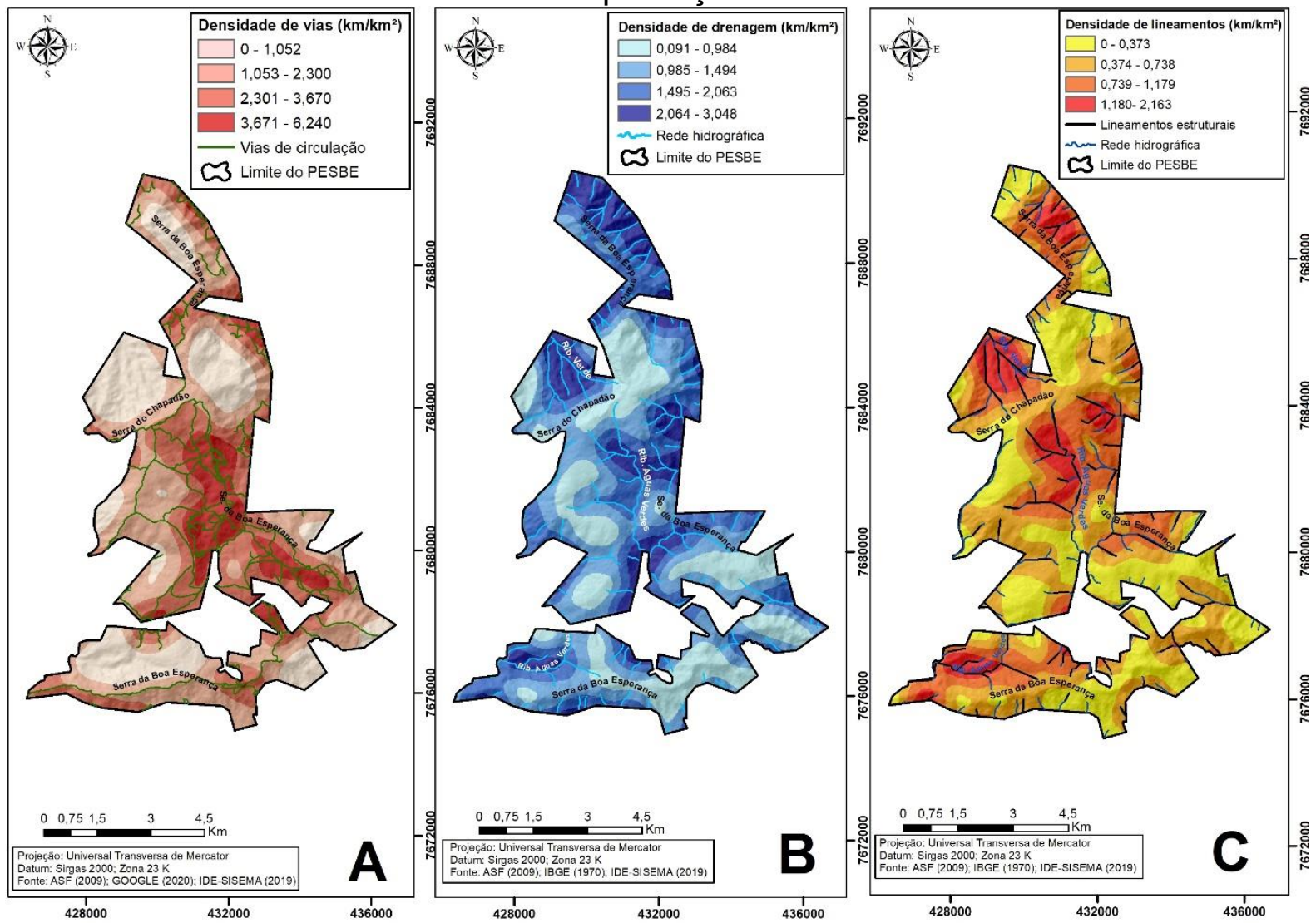

Fonte: Elaborado pelos autores (2021)

Legenda: A - Mapa de densidade de vias de circulação

B - Mapa de densidade de drenagem

C - Mapa de densidade de lineamentos estruturais

\section{ANÁLISE INTEGRADA DO PESBE}

Foram delimitadas cinco unidades de relevo no PESBE (Figura 4), as quais foram discutidas considerando a integração entre suas características físicas e antrópicas.

A unidade 1, Interflúvio angular/agudo, se restringe espacialmente ao setor norte do PESBE, ocupando uma área de $0,99 \mathrm{~km}^{2}$, o que corresponde a apenas $2 \%$ da área total do parque. Se caracteriza morfologicamente como uma crista aguda, resistente à erosão, constituída por unidades quartzíticas da Sequência Serra da Boa Esperança 2, conforme estudos de Valeriano (1992), Valeriano et al. (2007) e Ribeiro et al. (2020). Apresenta altitudes que variam predominantemente entre 937 a $1242 \mathrm{~m}$ e declividades majoritariamente altas, variando entre 30,87 a $76,4 \stackrel{\circ}{\text {. }}$ 
Figura 4. Mapa das Unidades de Relevo do Parque Estadual Serra da Boa Esperança, MG

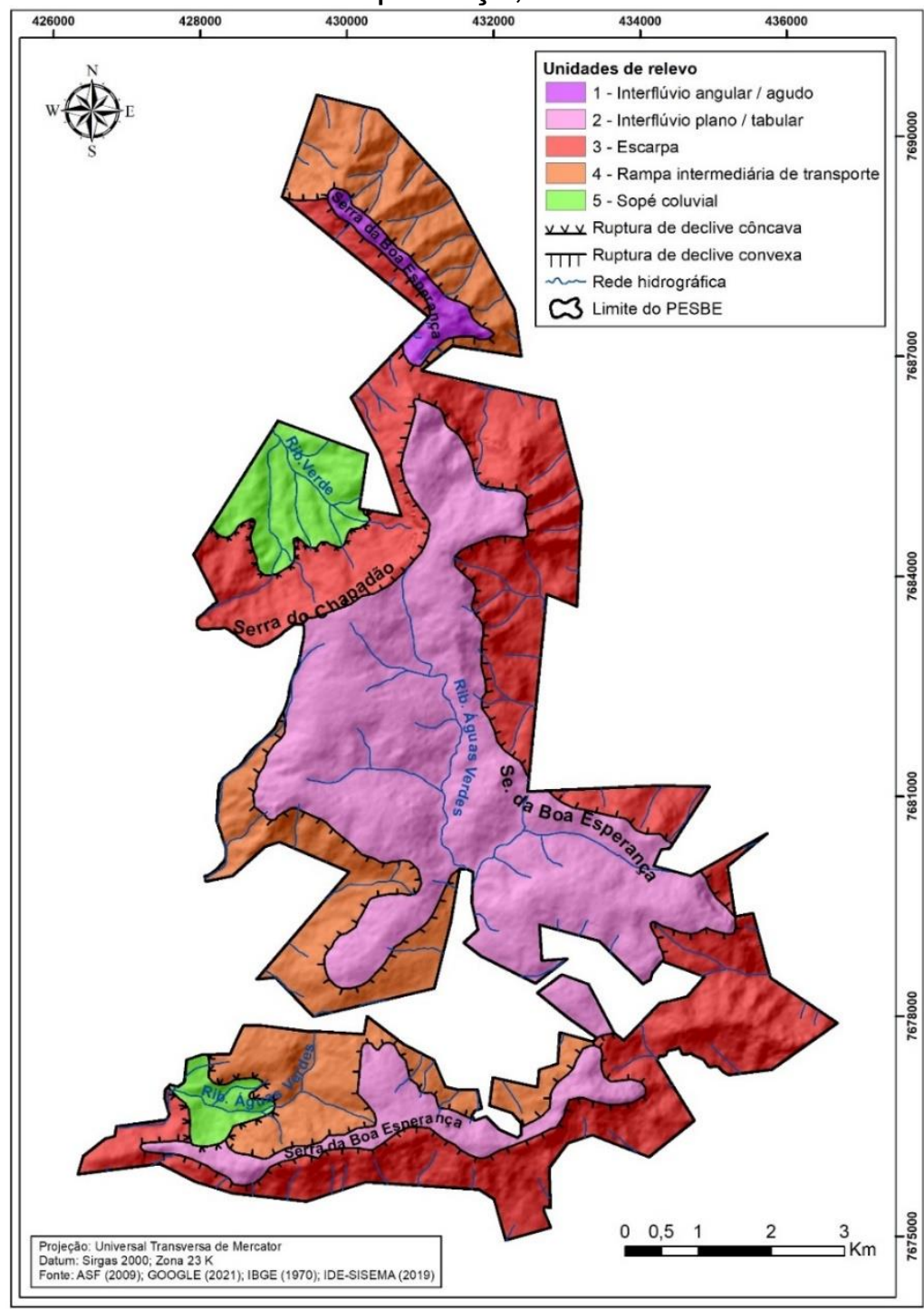

Fonte: Elaborado pelos autores (2021)

É considerada uma unidade emissora (SATO; CUNHA, 2013), pois além de apresentar níveis topográficos mais elevados em relação ao relevo adjacente, é onde se inicia os canais de $1^{\mathrm{a}}$ ordem, que escoam nas unidades 3 (Escarpas) e 4 (Rampa Intermediária de Transporte). Devido a sua peculiaridade morfológica, o uso e cobertura da terra é restrito, predominando campo limpo e campo sujo e apresentando pequenas áreas de mata e de pastagem em sua porção meridional.

A densidade de vias de circulação nesta unidade varia de baixa (0 a 1,052 $\mathrm{km} / \mathrm{km}^{2}$ ) em sua porção mais à norte, resultante das dificuldades de acessibilidade impostas pelo relevo, a média $\left(1,053\right.$ a $\left.3,670 \mathrm{~km} / \mathrm{km}^{2}\right)$, em sua porção meridional. Quanto a densidade de drenagem e a densidade de lineamentos estruturais, são observados valores intermediários em ambas as variáveis, variando entre 1,495 a $2,063 \mathrm{~km} / \mathrm{km}^{2}$ na densidade de drenagem e entre 0,374 a $1,179 \mathrm{~km} / \mathrm{km}^{2}$ na densidade de lineamentos estruturais. 
A unidade 2, Interflúvio plano/tabular, é a unidade predominante no PESBE, ocupando $38 \%$ de seu território, o que equivale a $22,35 \mathrm{~km}^{2}$, abrangendo os setores central, centro-norte, centro-sul, sudeste e sul. Apresenta morfologia caracterizada por topos planos/tabulares a secundariamente arredondados em faixas altimétricas mais elevadas da área, variando de 1.243 a $1.395 \mathrm{~m}$, atribuindo a esta unidade uma superfície de cimeira. Em toda sua extensão, a unidade é demarcada pelas serras do Chapadão a noroeste e a Serra da Boa Esperança a leste e ao sul, delimitadas em suas bordas por rupturas de declive convexa. Os declives de 0 a 20,37 ocorrem predominantemente em grande parte da área e, isoladamente, os declives mais

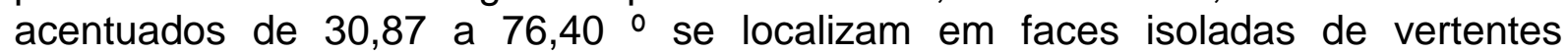
escarpadas. O substrato geológico, similar a unidade 1, é constituído pelas unidades quartzíticas da Sequência Serra da Boa Esperança 2 (VALERIANO 1992; VALERIANO et al., 2007; RIBEIRO et al., 2020). Sobre essas formas de relevo altas e pouco declivosas, o uso e cobertura da terra é caracterizado pela presença de campos limpos, os quais se intercalam com fragmentos de mata e campo sujo, além de uma área de silvicultura, no setor centro-sul.

Em sua porção localizada no setor central do PESBE, o Interflúvio plano/tabular apresenta uma área dotada de altas densidades de drenagem (2,064 a 3,048 km/km²), de lineamentos estruturais $\left(1,180\right.$ a 2,163 $\left.\mathrm{km} / \mathrm{km}^{2}\right)$ e de vias de circulação $(3,671$ a $\left.6,240 \mathrm{~km} / \mathrm{km}^{2}\right)$, atreladas a parte alta da bacia do Ribeirão Águas Verdes e a Serra da Boa Esperança.

Boa parte da bacia do Ribeirão Águas Verdes, caracterizado como um canal de $3^{\text {a }}$ ordem que, juntamente com seus diversos tributários, é o principal elemento responsável pela dissecação do relevo do PESBE, se desenvolve na unidade Interflúvio plano/tabular. A nascente do Ribeirão Águas Verdes, bem como a de seus tributários, se localiza em cotas altimétricas mais elevadas (1.243 a $1.395 \mathrm{~m})$ onde se encontram as superfícies de cimeira.

A rede hidrográfica da bacia do Ribeirão Águas Verdes apresenta vários trechos fortemente angulosos e formas anômalas, como cotovelos e meandros isolados, além de lineamentos estruturais consideravelmente extensos, a exemplo de um lineamento de $1.091 \mathrm{~m}$, indicando que a bacia apresenta um certo controle estrutural. Os diversos canais da bacia do Ribeirão Águas Verdes, bem como a presença considerável de lineamentos estruturais em seus domínios está espacialmente relacionada a uma grande quantidade de vias de circulação, expressa majoritariamente por trilhas oriundas da atividade de motociclismo Off-Road, que se encontram sobre a crista da Serra da Boa Esperança e nas vertentes da bacia do Ribeirão Águas Verdes, ambas pertencentes a unidade Interflúvio plano/tabular. A rede de trilhas que se estabelece nestas áreas promove a remoção da vegetação predominantemente campestre e da camada superficial do solo, além de compactar a superfície inicial. Esta situação dificulta a penetração de raízes e a consequente regeneração natural da área, acelerando a retomada erosiva produzida pelas chuvas.

Considerando que a unidade 2 é uma unidade emissora (SATO; CUNHA, 2013) em relação às demais unidades adjacentes, esta fornece material para as áreas a jusante. A associação, no setor central do parque, entre uma vegetação majoritariamente campestre, que intercepta uma menor porcentagem da precipitação se comparada a vegetação florestal (BIGARELLA, 2007); as altas densidades de drenagem e de lineamentos estruturais, que caracterizam, por um lado, um relevo em que ocorre o predomínio do escoamento superficial sobre a infiltração (CHRISTOFOLETTI, 1980) e, por outro, zonas atacadas mais facilmente por processos erosivos (SOARES; FIORI, 1978), além da intensa concentração de vias, 
que alteram a dinâmica natural das bacias, contribuindo na dissecação do solo e da vertente (CUNHA; THOMAZ, 2017), faz com que estes terrenos da unidade 2 sejam potencialmente mais susceptíveis aos processos de erosão do solo e, consequentemente, apresentem um maior potencial para fornecer sedimentos as unidades de relevo adjacentes, além de áreas externas ao PESBE, como o Reservatório de Furnas, considerando que grande parte do sistema hidrográfico do parque desagua neste reservatório.

Tal constatação se torna ainda mais preocupante na medida em que as trilhas podem reter combustível proveniente de vazamento das motos em seus leitos (SOUZA; BINKOWSKI, 2016). Devido à proximidade das trilhas e dos rios no setor central, durante episódios de chuvas o combustível retido pode ser transportado até corpos d'água a jusante das trilhas, contaminando-os e consequentemente contaminando o reservatório de Furnas.

A unidade 3, Escarpa também possui ampla distribuição no PESBE, ocupando $34 \%$ da área total da UC, ou 20,01 $\mathrm{km}^{2}$. Acompanha e delimita grande parte da unidade 2 (Interflúvio plano/tabular), bem como acompanha o sistema montanhoso e as vertentes das serras da Boa Esperança e do Chapadão, abrangendo os setores norte, nordeste, leste, sudeste e sul da Serra da Boa Esperança, nas proximidades do limite do parque, e noroeste da Serra do Chapadão, onde encontram-se as nascentes do Ribeirão Verde, rio de $3^{\underline{a}}$ ordem responsável pela dissecação da Serra do Chapadão dentro dos limites da UC. É caracterizada por um substrato geológico constituído pela unidade metapelítica da Sequência Serra da Boa Esperança 1 (VALERIANO 1992; VALERIANO et al., 2007; RIBEIRO et al., 2020) formada por filitos sericíticos cinzentos ou esverdeados e metarritmito arenoso.

A unidade 3 possui altitudes predominantemente intermediárias, variando entre 937 a $1.242 \mathrm{~m}$, e declividades, de modo geral, variando de médias a altas (entre 11,99 a $\left.76,4^{\circ}\right)$. O uso e cobertura da terra é heterogêneo, ocorrendo principalmente a presença de matas, mas também pastagens, campo limpo, campo sujo, cultivo de café e pequenas áreas com solo exposto.

No que se refere as densidades de drenagem, lineamentos estruturais e vias de circulação, destaca-se uma bacia hidrográfica de $2^{2}$ ordem localizada nos setores leste e nordeste, nas proximidades do limite do parque, pois a mesma apresenta manchas de alta densidade de drenagem $\left(2,064\right.$ a $\left.3,048 \mathrm{~km} / \mathrm{km}^{2}\right)$ e de lineamentos estruturais $\left(1,180\right.$ a $\left.2,163 \mathrm{~km} / \mathrm{km}^{2}\right)$, além de uma densidade de vias de circulação variando de intermediária a alta $\left(1,053\right.$ a $\left.6,240 \mathrm{~km} / \mathrm{km}^{2}\right)$. Como mencionado anteriormente, a conjunção entre essas variáveis ocasiona uma maior tendência à erosão dos solos e a dissecação do relevo, o que é agravado devido aos altos índices de declividade encontrados nas áreas de cabeceira de drenagem da bacia, levandose em consideração o fato de que a declividade

guarda relação direta com a velocidade de transformação da energia potencial em energia cinética e, portanto, com a velocidade das massas de água em movimento responsáveis pelo "runoff"' (CREPANI et al., 2001, p. 75).

Atrelada a estes fatores, é importante ressaltar a presença de pastagens na bacia hidrográfica mencionada, uma vez que nesta classe de uso da terra é comum ocorrer a compactação do solo e a criação de caminhos preferenciais para 0 escoamento superficial, o que aumenta o risco de erosão (BOTELHO; SILVA, 2004). 
A unidade Escarpa abriga diversos canais que nascem nas proximidades do limite do PESBE se desenvolvendo nas áreas externas ao parque. É caracterizada como transmissora (SATO; CUNHA, 2013), conduzindo os materiais advindos das unidades emissoras para as áreas a jusante, de maneira relativamente rápida, pois a mesma possui rampas declivosas e alongadas, favorecendo o incremento da velocidade do escoamento fluvial (PIRES NETO, 1991; SALOMÃO, 2020). Nesse sentido, destaca-se o setor leste do parque, pois além de se situar a jusante de uma área emissora com grande potencial de produção de sedimentos (a área que abrange a bacia do Ribeirão Águas Verdes e a crista da Serra da Boa Esperança, na unidade 2), o mesmo localiza-se próximo ao reservatório de Furnas, estando a ele conectado por diversos canais fluviais; fazendo com que este setor possa transmitir rapidamente os materiais advindos das unidades mais elevadas para o reservatório. Ressalta-se que, devido as suas características físicas e antrópicas, o setor leste do PESBE também apresenta um grande potencial para produzir seus próprios sedimentos e, posteriormente, transmiti-los ao lago artificial.

A unidade 4, Rampa Intermediária de Transporte é caracterizada como uma unidade de relevo transmissora (SATO; CUNHA, 2013), apresentando área de 11,89 $\mathrm{km}^{2}$, o que equivale a $20 \%$ da área do PESBE. Abrange áreas dos setores norte (ocupando grande parte de seu território), oeste, centro-oeste, centro-sul e sul. Se diferencia da unidade 3 (Escarpa) por apresentar, de modo geral, declividades mais suaves, que variam de 0 a 20,37으 em sua maior parte, principalmente nos setores sul e centro-sul, e pontualmente declives maiores ( 30,87 a 76,4 $\stackrel{\circ}{)}$, localizados nos setores norte e centro-oeste. Além desta característica, morfologicamente as rampas são superfícies longas delimitadas por rupturas de declive convexa acompanhando a unidade 1 (Interflúvio angular/agudo) e a unidade 2 (Interflúvio plano/tabular). São constituídas em sua maioria, pelo mesmo substrato rochoso da unidade 3 (Escarpas), ou seja, unidade metapelítica da Sequência Serra da Boa Esperança 1 (VALERIANO 1992; VALERIANO et al., 2007; RIBEIRO et al., 2020). Ao sul do parque, com ocorrência restrita, aparecem Granitos e ortognaisses miloníticos e/ou filonitizados na face norte da Serra da Boa Esperança, abrangendo um trecho a montante da bacia do ribeirão Águas Verdes. Encontra-se em faixas altimétricas baixas e intermediárias, variando entre 783 a $1242 \mathrm{~m}$, e apresenta uso e cobertura da terra diversificado, observando-se as classes Mata, Campo Limpo, Campo Sujo, Pastagem, Cultivo Agrícola (café) e Solo Exposto.

Esta unidade de relevo abriga algumas áreas com alta densidade de drenagem (2,064 a 3,048 km/ $\left./ \mathrm{km}^{2}\right)$, encontradas principalmente no setor norte do PESBE. Neste setor, a alta densidade de drenagem está relacionada a diversos canais de $1^{\text {a }}$ e $2^{\underline{a}}$ ordem, cujos vales são formados por interflúvios perpendiculares a Serra da Boa Esperança, onde observa-se uma cobertura da terra representada pelo mosaico de mata, campo sujo e pastagem. Vários dos canais fluviais que ali ocorrem apresentam trechos retilíneos, demonstrando a presença de lineamentos estruturais que refletem em uma mancha de alta densidade de lineamentos $\left(1,180\right.$ a 2,163 km/ $\left.\mathrm{km}^{2}\right)$. Nas áreas da Rampa intermediária de transporte mais próximas ao limite do PESBE, no setor norte, existem diversos trechos de trilhas que se conectam a propriedades fora dos limites da UC, refletindo em uma faixa estreita de alta densidade de vias de circulação $\left(3,671\right.$ a $\left.6,240 \mathrm{~km} / \mathrm{km}^{2}\right)$.

É importante ressaltar que assim como o setor leste, o setor norte localiza-se muito próximo ao Reservatório de Furnas, estando conectado ao mesmo através dos canais fluviais. Nesse sentido, a unidade 4, presente neste setor, caracterizada como uma unidade transmissora que localmente apresenta vertentes alongadas, por vezes 
suaves e íngremes, polígonos de solo exposto e intensa rede hidrográfica, também possui relevante potencial para provocar a sedimentação do reservatório.

A unidade 5, Sopé Coluvial, é a segunda menor unidade do PESBE, abrangendo apenas $6 \%$ de seu território, ou 3,49 $\mathrm{km}^{2}$. Sua localização se restringe aos trechos médio e inferior da bacia do Ribeirão Verde, no setor noroeste, cujo substrato rochoso é constituído pela Formação Samburá - metapelito maciço ou laminado (VALERIANO 1992; VALERIANO et al., 2007; RIBEIRO et al., 2020), e o trecho inferior da bacia do Ribeirão Águas Verdes, no setor sul do parque, onde ocorrem Granitos e ortognaisses miloníticos e/ou filonitizados (VALERIANO 1992; VALERIANO et al., 2007; RIBEIRO et al., 2020). Apresenta altitudes variando entre 783 a $1089 \mathrm{~m}$, e valores de declividade predominantemente variando de baixos (0 a $\left.11,98^{\circ}\right)$ a intermediários $\left(11,99\right.$ a $\left.30,86^{\circ}\right)$. Devido a área reduzida e a localização restrita no parque, o uso e cobertura da terra é pouco heterogêneo, correspondendo apenas a mata, campo sujo e pastagem.

A unidade 5, ao mesmo tempo em que apresenta altas densidades de drenagem $\left(2,064\right.$ a $\left.3,048 \mathrm{~km} / \mathrm{km}^{2}\right)$ e de lineamentos estruturais $(1,180$ a 2,163 $\mathrm{km} / \mathrm{km}^{2}$ ), devido a presença de vários canais fluviais, que chegam a possuir até hierarquia de $3^{\underline{a}}$ ordem, e que possuem diversos trechos retilíneos e formas anômalas; não apresenta vias de circulação, ocasionando uma densidade de vias majoritariamente baixa (0 a $1,052 \mathrm{~km} / \mathrm{km}^{2}$ ).

A ausência de vias de circulação, e mais especificamente das trilhas provocadas pelo motociclismo Off-Road na unidade Sopé coluvial pode ser explicada pelas dificuldades impostas pelo ambiente ao desenvolvimento desta atividade antrópica, na medida em que a associação entre a cobertura vegetal formada principalmente por fragmentos florestais e matas ciliares, e a densa rede hidrográfica cria barreira natural a prática plena desta atividade, garantindo maior preservação desta unidade de relevo.

Como unidade coletora, o Sopé coluvial foi delimitado por ruptura de declive côncava sendo caracterizado como área de acumulação. Recebe os fluxos de matéria e energia advindos das demais unidades de relevo (SATO; CUNHA, 2013), estando, por conseguinte propenso a abrigar ampla carga de sedimentos. Nesse sentido, a área desta unidade correspondente a baixa bacia do Ribeirão Águas Verdes, no setor sul do PESBE corre maior risco de sofrer um processo de sedimentação do que a área da baixa bacia do Ribeirão Verde, no setor noroeste. Essa afirmativa se justifica, pois, a bacia do Ribeirão Águas Verdes possui uma extensão muito superior dentro dos limites do parque, permitindo que seus canais acumulem mais sedimentos, além do fato de que sua porção superior, na unidade Interflúvio plano/tabular, apresenta um grande potencial para a produção de sedimentos. Ainda assim, a área na bacia do Ribeirão Verde também pode sofrer um processo de sedimentação, uma vez que é delimitada pela unidade Escarpa, que oferece alta susceptibilidade aos processos denudacionais (SATO; CUNHA, 2013), especialmente quando se considera a baixa proteção ao solo oferecida pela cobertura vegetal que a recobre, composta por campo limpo.

\section{CONSIDERAÇÕES FINAIS}

Com os resultados deste trabalho, ficou evidenciado que o Parque Estadual Serra da Boa Esperança se caracteriza como um sistema ambiental complexo, apresentando relevo serrano condicionado pelas características litoestruturais, e 
cobertura vegetal que, em grande parte de seu território, abriga uma vegetação pouco vigorosa, típica do Cerrado.

A unidade Interflúvio plano/tabular é predominante no PESBE, ocupando $38 \%$ de sua área; seguida pela unidade Escarpa, com $34 \%$ e pela unidade Rampas Intermediárias de Transporte com $20 \%$ da área do parque. As demais unidades, Interflúvio angular/agudo e Sopé Coluvial, possuem área pequena totalizando apenas, $2 \%$ e $6 \%$, respectivamente.

Destaca-se que na unidade Interflúvio plano/tabular, a vegetação esparsa formada por campo limpo e campo sujo e secundariamente por fragmentos de mata, facilita a ocorrência de diversas trilhas, que são abertas por praticantes de motociclismo Off Road. Esta prática, muito frequente no PESBE, causa remoção da vegetação e da camada superficial do solo, contribuindo para a aceleração dos processos morfogenéticos, mediante o direcionamento do escoamento superficial, bem como a compactação do solo pelas motocicletas.

A unidade Escarpa, apresenta em sua maioria, declividades altas e são cobertas por matas, ocorrendo secundariamente pastagens, campo limpo, campo sujo, cultivo de café e pequenas áreas com solo exposto. Grande parte dos canais fluviais pertencentes as principais bacias do PESBE e do reservatório de Furnas, nascem e escoam por esta unidade. A unidade Rampa Intermediária de Transporte, apresenta os mesmos usos da unidade Escarpa, porém inclui nela pequenas áreas de cultivos de café próximo aos limites da UC. Comumente ocorrem trilhas que se conectam a propriedades rurais fora dos limites da UC, promovendo alta densidade de vias de circulação.

A unidade Interflúvio angular/agudo é formada, em sua maioria, por campo limpo e campo sujo apresentando baixa densidade de vias de circulação em função das dificuldades impostas pelo relevo. A unidade Sopé Coluvial abrange as duas principais bacias do PESBE, a bacia do ribeirão Verde a noroeste e a bacia do ribeirão Águas Verdes ao sul do parque. Estas apresentam predominância de fragmentos florestais e matas ciliares e baixa densidade de vias de circulação, onde trilhas provocadas pelo motociclismo Off-Road são ausentes. A presença da cobertura vegetal aliada a alta densidade de drenagem torna-se barreira natural a prática da atividade, garantindo maior preservação da UC.

Considerando as características das variáveis geoambientais do PESBE bem como o fato de o plano de manejo da referida UC ainda não ter sido concretizado, recomenda-se que sejam tomadas medidas para cessar as atividades antrópicas que não coincidam com os objetivos do parque, uma vez que, segundo Santos (2010), foi determinado pelo artigo 27 da lei do SNUC que em todas as unidades de conservação que não disponham de plano de manejo são proibidas atividades que não sejam de conservação e fiscalização.

Por fim, recomenda-se que sejam tomadas medidas de educação ambiental por parte dos órgãos competentes para que os frequentadores do parque sejam conscientizados sobre o papel que o PESBE possui enquanto unidade de conservação. Apesar de ser permitida a visitação, o objetivo principal da UC é a preservação do rico sistema ambiental que é a Serra da Boa Esperança.

\section{AGRADECIMENTOS}

O presente trabalho foi realizado com apoio da Coordenação de Aperfeiçoamento de Pessoal de Nível Superior - Brasil (CAPES) - Código de Financiamento 001. 


\section{REFERÊNCIAS BIBLIOGRÁFICAS}

AB'SABER, A. N. Os domínios de natureza no Brasil: potencialidades paisagísticas - $7^{\mathrm{a}}$ ed. São Paulo: Ateliê Editorial, 2012.

ALASKA SATELLITE FACILITY. DATA SEARCH VERTEX. 2020. Disponibiliza o download de produtos de sensoriamento remoto. Disponível em: https://search.asf.alaska.edu/\#/?dataset=ALOS. Acesso em: 14 jul. 2020.

ALVES, C. S. Levantamento de mamíferos de médio e grande porte do Parque Estadual Serra da Boa Esperança, Minas Gerais: contribuições para o plano de manejo. 2019. Trabalho de Conclusão de Curso (Bacharelado em Ciências biológicas) - Universidade Federal de Lavras, Lavras, 2019.

ALVES, V. E. L. Expansão do Agronegócio e os Impactos Socioambientais na Região de Cerrados do Centro-Norte do Brasil (MATOPIBA). Confins, n. 45, 2020.

ARCGIS. World Imagery. Fornece imagens de satélite com diversas resoluções espaciais. Disponível em: https://www.arcgis.com/home/item.html?id=10df2279f9684e4a9f6a7f08febac2a9. Acesso em: 25 mai. 2021.

BIGARELLA, J. J. Estrutura e origem das paisagens tropicais e subtropicais. 2. ed. Florianópolis: Ed. Da UFSC, 2007.

BOTELHO, R. G. M.; SILVA, A. S. da. Bacia Hidrográfica e Qualidade Ambiental. In: VITTE, A.C.; GUERRA, A. J. T. (orgs). Reflexões sobre a Geografia Física no Brasil. Rio de Janeiro: Bertrand Brasil, 2004. cap. 6, p. 153-188.

BRASIL. Lei no 9.985, de 18 de julho de 2000. SNUC - Sistema Nacional de Unidades de Conservação. Publicado no D.O.U. de 19 de julho de 2000.

CÂMARA, G.; CARVALHO, M. S. Análise de processos pontuais. São José dos Campos: INPE, 2002.

CHRISTOFOLETTI, A. Geomorfologia. São Paulo: Editora Edgard Blücher, 1980

CONTI, J. B.; FURLAN, S. A. Geoecologia: o clima, os solos e a biota. In.: ROSS, J. L. S. (org.) Geografia do Brasil - 6ª ed. São Paulo: Edusp, 2011.

COUTINHO, C. B.; ANDRADE, D. P. Levantamento da avifauna no Parque Estadual Serra da Boa Esperança. In: Congresso Nacional de Meio Ambiente de Poços de Caldas, 14., 2016, Poços de Caldas. Anais [...]. Poços de Caldas: GSC Eventos Especiais \& IF Sul de Minas, 2016. n.p.

COUTO JUNIOR, A. F.; SOUZA, V. V.; CARVALHO JUNIOR, O. A.; MARTINS, E. S.; SANTANA, O. A.; FREITAS, L. F.; GOMES, R. A. T. Integração de parâmetros morfométricos e imagem ASTER para a delimitação das fitofisionomias da Serra da 
Canastra, Parque Nacional da Serra da Canastra - MG. Revista Brasileira de Geomofologia, v. 11, n. 1, p. 57-68, 2010.

CREPANI, E.; MEDEIROS, J. S.; FILHO, P. H.; FLORENZANO, T. G.; DUARTE, V.; BARBOSA, C. C. F. Sensoriamento Remoto e Geoprocessamento Aplicados ao Zoneamento Ecológico-Econômico e ao Ordenamento Territorial. São José dos Campos: INPE, 2001.

CUNHA, M. C. da.; THOMAZ, E. L. Fluxo subsuperficial interceptado por estrada rural: características e distribuição na paisagem. Boletim Goiano de Geografia, Goiânia, v.3, n.3, p. 429-447, 2017.

DURIGAN, G.; RATTER, J. A. The need for a consistent fire policy for Cerrado conservation. Journal of Applied Ecology, v. 53, p. 11-15, 2016.

FERREIRA, M. C. Iniciação à análise geoespacial: teoria, técnicas e exemplos para geoprocessamento. 1. ed. São Paulo: Editora Unesp, 2014.

FOSENCA FILHO, R. E.; VARAJÃO, A. F. D. C.; CASTRO, P. de T. A. Compactação e erosão de trilhas geoturísticas de parques do Quadrilátero Ferrífero e da Serra do Espinhaço Meridional. Revista Brasileira de Geomorfologia, v. 20, n. 4, p. 825-839, 2019.

FRANKE, J.; BARRADAS, A. C. S.; BORGES, M. A.; COSTA, M; M.; DIAS, P. A.; HOFFMANN, A. A.; OROZCO FILHO, J. C.; MELCHIORI, A. E.; SIEGERT, F. Fuel load mapping in the Brazilian Cerrado in support of integrated fire management. Remote Sensing of Environment, v. 217, p. 221-232, 2018.

GATTO, L. C. S.; RAMOS, V. L. S.; NUNES, B. T. A.; MAMEDE, L.; GÓES, M. H. B.; MAURO, C. A.; ALVARENGA, S. M.; FRANCO, E. M. S.; QUIRICO, A. F.; NEVES, L. B.; 1983. Geomorfologia, Folhas SF. 23/24 Rio de Janeiro/ Vitória ao Milionésimo. Levantamento de Recursos Minerais, Projeto RADAMBRASIL, Ministério de Minas e Energia. Rio de Janeiro, v.32. p.305-384.

GREGORY, K. J. A natureza da Geografia Física. Rio de Janeiro: Bertrand Brasil, 1992.

GUALTIERI-PINTO, L.; OLIVEIRA, F. F. de; ANDRADE, M. de A.; PEDROSA, H. F.; SANTANA, W. A. de; FIGUEIREDO, M. do A. Atividade Erosiva em Trilhas de Unidades de Conservação: Estudo de Caso no Parque Nacional da Serra do Cipó, Minas Gerais, Brasil. E- scientia, Belo Horizonte, v.1, n.1, p.1-16, 2008.

HOWARD, A. D. Drainage analysis in geologic interpretation: a summation. AAPG Bulletin. Virgínia-USA, v. 51, n. 11, p. 2246-2259, 1967.

IBGE. IBGE CIDADES. 2017. Disponibiliza informações sobre municípios brasileiros. Disponível em: https://cidades.ibge.gov.br/brasil/mg/boa-esperanca/panorama. Acesso em: 22 fev. 2020. 
IEF. Parque Estadual Serra da Boa Esperança. Disponibiliza informações sobre o parque. Disponível em: http://www.ief.mg.gov.br/noticias/280?task=view. Acesso em: 15 fev. de 2020.

MARTINS, M. L. Olhares sobre o "Mar de Minas": percepções dos moradores de Alfenas e Fama relativas ao Lago de de Furnas (1963-1999). Ambiente \& Sociedade, v.13, n.2, p. 347-363, 2010.

MESSIAS, C. G.; FERREIRA, M. C. Modelo Geoespacial para a Identificação de Áreas com Perigo de Propagação de Queimadas no Parque Nacional da Serra da Canastra. Revista do Departamento de Geografia, v. 38, p. 154-168, 2019.

MORANDI, D. T.; FRANÇA, L. C. J.; MENEZES, E. S.; MACHADO, E. L. M.; SILVA, M. D.; MUCIDA, D. P. Delimitation of ecological corridors between conservation units in the Brazilian Cerrado using a GIS and AHP approach. Ecological indicators, v. 115, 2020.

MINAS GERAIS. Decreto no 44.520, de 16 de maio de 2007. Cria o Parque Estadual Serra da Boa Esperança, e declara de utilidade pública, para desapropriação de pleno domínio, os imóveis a que se refere, no município de Boa Esperança. Diário do Executivo: Minas Gerais, p.2, col.2, 17 mai. 2007.

MORAIS, T. H. B.; MORAIS, W. L.; CAMARGO, A. S. O; PIMENTA, A. P. Aspectos da historicidade e criação do Parque Estadual Serra da Boa Esperança, Boa Esperança, MG. In: JORNADA CIENTÍFICA E TECNOLÓGICA E 3 SIMPÓSIO DE PÓS-GRADUAÇÃO DO IFSULDEMINAS, 6, 2014. POUSO ALEGRE/ MG. Anais... Pouso Alegre: 2014. p. 1-7.

OLIVEIRA, U.; SOARES-FILHO, B. S.; PAGLIA, A. P.; BRESCOVIT, A. D.; CARVALHO, C. J. B de.; SILVA, D. P.; REZENDE, D. T.; LEITE, F. S. F.; BATISTA, J. A. N.; BARBOSA, J. P. P. P.; STEHMANN, J. R.; ASCHER, J. S.; VASCONCELOS, M. F.; MARCO, P.; LÖWENBERG-NETO, P.; FERRO, V. G.; SANTOS, A. J. Biodiversity conservation gaps in the Brazilian protected areas. Scientific Reports, v. 7, 2017.

PDRH FURNAS. Plano diretor de recursos hídricos da Bacia Hidrográfica do entorno do lago de Furnas: Diagnóstico da Bacia Hidrográfica. Alfenas: ALAGO; FUPAI, 2013. 305 p.

RANGEL, M. S. Situação fundiária do Parque Estadual Serra da Boa Esperança, Minas Gerais. 2017. Monografia (Especialização MBA em Gestão Ambiental) Universidade Federal do Paraná, Curitiba, 2017.

RIBEIRO, A.; TROUW, R. A. J.; PACIULLO, F. V. P.; NASCIMENTO, D. B.; CAMPOS, M. T. R.; NETO, V. C.; VALERIANO, C. de M.; DUSSIN, I. Geologia e recursos minerais da folha Alfenas SF.23-V-D-I. Rio de Janeiro: CPRM/UFRJ, 2020. 1 mapa. Escala 1:100.000. 
RIBEIRO, J. F.; WALTER, B. M. T. Fitofisionomias do bioma Cerrado. In.: SANO, S. M.; ALMEIDA, S. P. (eds.). Cerrado: ambiente e flora. Brasília: Embrapa Cerrados, 1998.

ROLDAN, L. F.; MACHADO, R.; STEINER, S. dos. S.; WARREN, L. V. Análise de lineamentos estruturais no Domo de Lages (SC) com uso de imagens de satélite e mapas de relevo sombreado. Revista do Instituto de Geociências - USP, [s. I.], v. 10, n. 2, p. 57-72, 2010.

ROSS, J. L. S. A sociedade industrial e o ambiente. In.: ROSS, J. L. S. (org.) Geografia do Brasil - 6ª ed. São Paulo: Edusp, 2011.

SALOMÃO, F. X. de. T. Controle e prevenção dos processos erosivos. In: GUERRA, A. J. T.; SILVA, A. S. da; BOTELHO, R. G. M. (orgs). Erosão e conservação dos solos. 11. ed. Rio de Janeiro: Bertrand Brasil, 2020. cap. 7, p. 229-267.

SANTOS, A. M. dos. O ecoturismo, uso público e o Parque Nacional do Iguaçu. Fórum Ambiental da Alta Paulista, v.6, n.3, p.229-242, 2010.

SANTOS, G. L.; PEREIRA, M. G.; DELGADO, R. C.; MAGISTRALI, I. C.; SILVA, C. G.; OLIVEIRA, C. M. M.; LARANGEIRA, J. P. B.; SILVA, T. P. Degradation of the Brazilian Cerrado: Interactions with human disturbance and environmental variables. Forest Ecology and Management, v. 482, 2021.

SATO, S. E.; CUNHA, C. M. L. Carta de unidades geoambientais do município de Itanhaém, São Paulo, Brasil. Revista da Gestão Costeira Integrada, v.13, n. 3, p. 329-342, 2013.

SILVA, A. O. da; CASTRO, A. O. C. de. Avaliação dos impactos de uso público na trilha ecológica da Praia do Perigoso- Parque Natural de Grumari, RJ. Revista Eletrônica Uso Público em Unidades de Conservação, v.3, n.5, p.1-12, 2015.

SOARES, P. C.; FIORI, A. P. Lógica e Sistemática na Análise e Interpretação de Fotografias Aéreas em Geologia. Notícia Geomorfológica, Campinas, v. 16, n. 32, p. 71-104, 1978.

SOUZA, R. A. de; BINKOWSKI, P. Impactos socioambientais causados pela prática de Motocross no município de São Francisco de Paula/RS. Revista Eletrônica Científica da UERGS, Porto Alegre, v.2, n.3, p.207-216, 2016.

VALERIANO, C. M. Evolução tectônica da extremidade meridional da Faixa Brasília, região da Represa de Furnas, Sudoeste de Minas Gerais. 1992. Tese (Doutorado) - Instituto de Geociências, Universidade de São Paulo, 1992. Inédito.

VALERIANO, C. de M.; PEREIRA, R. M.; ALMEIDA, J. C. H. de; DUARTE. B. P.; TURBAY, C.; ROSSI, A.; GONTIJO, A.; RIBEIRO, A.; NOGUEIRA, J. R.; HEILBRON, M.; CASTRO, C.; FALCAO, T. da C.; SILVA, V. G. M. da R. Mapa geológico folha de Guapé - SF.23-V-B-IV. Minas Gerais: UERJ/CPRM, 2007. 1 mapa. Escala 1:100.000: nota explicativa integrada com Alpinópolis. 
ZHOU, Q.; LIU, X. Analysis of errors of derived slope and aspect related to DEM data properties. Computers \& Geosciences, v. 30, p. 369-378, 2004.

ZIMBRES, B.; SHIMBO, J.; BUSTAMANTE, M.; LEVICK, S.; MIRANDA, S.; ROITMAN, I.; SILVÉRIO, D.; GOMES, L.; FAGG, C.; ALENCAR, A. Savanna vegetation structure in the Brazilian Cerrado allows for the accurate estimation of aboveground biomass using terrestrial laser scanning. Forest Ecology and Management, v. 458, 2020. 